\title{
多肢選択テストの部分的知識による得点増加 を評価するための数学モデル
}

\author{
有 田 清三郎*, 斎 藤 泰 一**, 那 須 郁 夫*** \\ MATHEMATICAL MODELS TO ASSESS THE CONTRIBUTION OF THE \\ PARTIAL KNOWLEDGE OF EXAMINEES TO THE \\ SCORES OF MULTIPLE-CHOICE TEST \\ Seizaburo ARITA*, Taiichi SAITO** and Ikuo NASU***
}

\begin{abstract}
To assess the contribution of the partial knowledge of examinees to the scores of multiple -choice tests, we have proposed two mathematical models, the Binary-model and the Terminal model. These models both were based on the probability with which an examinee recognizes a choice correctly, and on the arrangement of choices.

As an application of these models, the distributions of scores were given for the one-best -response type and the two-responses type of questions of the national board examinations for the medical and dental practices. The distributions of scores by these two models were compared.
\end{abstract}

\section{1. はじめに}

医師・歯科医師国家試験をはじめ各種の国家試験や 資格検定試験に多肢選択方式による客観テストが採用 されつつある。記述式テストには千差万別の解答が準 備されその評点が採点者の主観的判断に大きく影響さ れるのに対して, 多肢選択テストでは, 正解は問題が つくられたと同時に決定され，採点が客観的で，コン ピューター採点なぞにより採点の労力が軽減される之 いら利点がある。しかしこの多肢選択方式は与兄られ た選択肢の中に正解が必ず存在することから，受験者 は正解を知らなくてもあて推量で正解できる場合が生 ずる。

多肢選択テストの得点に関する代表的な数学モデル

* 川崎医科大学数学教室 (Department of Mathematics, Kawasaki Medical School)

** 川崎医科大学薬理学教室 (Department of Pharmacology, Kawasaki Medical School)

*** 日本大学松戸歯学部衛生学教室 (Department of Dental Public Health, Nihon University, School of Dentistry at Matsudo)

この研究は財団法人操風会教育研究奖励金の援助を 受けて行なわれた。
はランダム・ゲッシング・モデルである(印東他, 1977). このモデルは次の仮定に基づいている.

仮定 1）ある特定の受験者に対して，与えられた問 題は次の二つのグループにわけられる，そのひと つは, 受験者がその問題を正しく理解し，したがっ て正しく解答できる問題のグループ（わかった問 題）で，もらひとつはとの問題が理解できず，乙 たがってどれが正解かを知らない問題のグループ （わからなかった問題）である。

仮定 2）わかった問題については受験者は必ず正 答できるものとする。すなわちわかった問題は確 率 1 で正答できるものとする。

仮定 3）わからない問題については受験者はあて 推量で解答するものとする。すなわちいまM個の 解答が用意され，そのうち 1 個が正解であるとき， 受験者があて推量で運よく正しい解答を選んで正 答する確率を $1 / \mathrm{M}$, 正しくない解答を選んで誤答 する確率を1-1/Mとする。

仮定 4） 受験者は問題を理解していようといまい と,与兄れれ問題は必ず解答するものとする。す なわち無解答はないものとする。

仮定 5）わからなかった問題に対してあて推量で 
解答を選ぶ方法は各問いに対して独立であるとす る.

ランダム・ゲッシング・モデルでは受験者は正解が

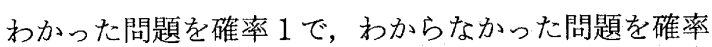
1/Mのあて推量で正答することになるから, 受験者の 得点は正答率 1 の確実な知識による得点と, 正答率 1 / Mのあて推量による得点とが合計されたものとなる。 このモデルによる正答数は 2 項分布に従い, 実際に得 られた正答数から, 正解者グループの割合の推定問題 などが研究されている（池田，1973）。

しかしながら現実の多肢選択テストでは，正答率は

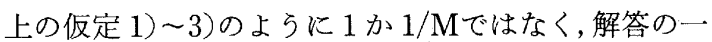
部分がわかった問題について受験者は二者択一, 三者 択一などを行うわけであるから，このランダム・ゲッ シング・モデルの正答率に，さらに $1 / 2,1 / 3, \ldots, 1 /$ $(\mathrm{M}-1)$ 及び 0 の正答率を加光たものが，受験者の現 実的な正答率を表わしているように思われる。いま,正 答率 $1,1 / 2, \ldots, 1 / \mathrm{M}$ 及び 0 で解答される問題数の割 合の組 $\left(\mathrm{P}_{1}, \mathrm{P}_{2}, \ldots, \mathrm{P}_{\mathrm{M}-1}, \mathrm{P}_{\mathrm{M}}, \mathrm{P}_{0}\right)=\mathrm{P}$ を多肢選択 テストに打ける受験者の正答率分布と名づける。

このような部分的な知識の割合を正答率 $(1 / 2,1 /$ $3, \ldots, 1 /(M-1))$ のそれで表現し，その得点分布に ついて考察した研究には, Chernoff (1962)などがあげ られるが，ここでは逆に，不十分な知識をすず選択肢 の正, 不正, 不明の判断とその配列によって表現し, こ れらの知識の状態の生起確率を導出するために, 2 項 モデル, ターミナル・モデルといら二つの数学モデル を提案する。

多肢選択テストは, その出題形式により，1正解形式 (単純真偽形式), 組合せ形式などに分類されるが，本 研究では 1 正解形式と多真偽形式のひとつのタイプを

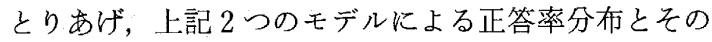
得点分布を求め, 比較検討した。この二つのモデルに よって不十分な知識の度合いを正答率の割合で数量的 に表現し，正答率 $1 / i$ の存在を具体的に明示した。 た 2 項モデルでは, 通常行われている平均得点を, ター ミナル・モデルでは識別した選択肢の数に応じて選択 肢テストにおける思考過程の一例を示した。 また数值 例によって，これらのモデルにより出題形式による得 点の変化を示した。

\section{2. 多肢選択テスト}

多肢選択テストの例をあげよう。

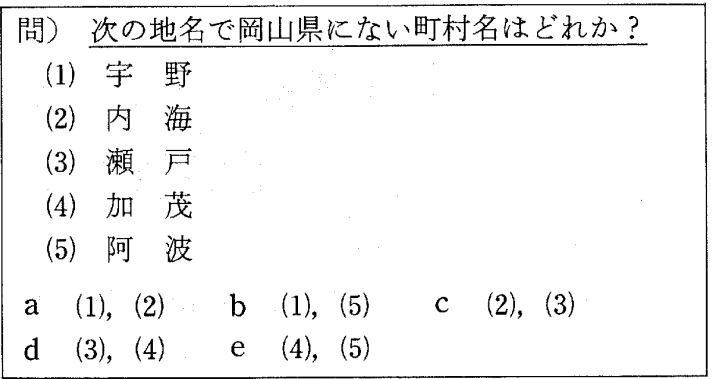

最初に多肢選択テストで使用する語句を次のよらに 定義する，多肢選択テストは「設問」，「選択肢」，「解 答コード」の 3 部分から構成されているものとする.上 の例での下線部の個所を設問，(1)，(2)，. . , (5) を選択 肢, a , b , . , e のそれぞれを解答コード, $(\mathrm{a}, \mathrm{b}, \ldots, \mathrm{e})$ を解答コード群と名づける。解答コード群にはいるい ろのタイプがあるが，最近の医師・歯科医師国家試験 に採用されているのは次の5つのタイプである。

\begin{tabular}{|c|c|}
\hline Type 1 & 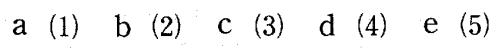 \\
\hline Type 2 & 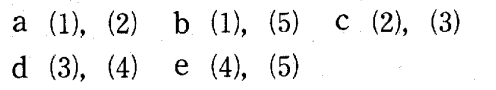 \\
\hline Type 3 & $\begin{array}{llllllll}\text { a } & (1), & (2), & (3) & \text { b } & (1), & (2), & (5) \\
\text { c } & (1), & (4), & (5) & d & (2), & (3), & (4) \\
\text { e } & (3), & (4), & (5) & & & & \end{array}$ \\
\hline Type 4 & $\begin{array}{l}\text { a (1), (3), (4) b (1), (2) } \\
\text { c (2), (3) d (4) のみ } \\
\text { e (1) (4)のすべて }\end{array}$ \\
\hline Type 5 & $\begin{array}{l}\text { a (1) b (2) c (3) d (4) } \\
\text { e (1) (4)のWずれですない }\end{array}$ \\
\hline
\end{tabular}

Type 1 は 1 正解形式, Type $2 \sim 4$ は多真偽形式, Type 5 は Type 1 の変形である。また Type $1 \sim 3$ は 5 個の選択肢, Type 4, 5 は 4 個の選択肢で構成されてい るが，ぞのダイプの解答コードも $(\mathrm{a}, \mathrm{b}, \ldots, \mathrm{e})$ となっ ているので，最終的に選ぶ選択肢として考党れば，い ずれのタイプも 5 肢選択となっている.

各選択肢は正答肢か不正肢のいずれかであるから， 出題形式の観点からながめると, 1正解形式では与兄 られた選択肢のいずれか 1 つが正答肢で, 他は不正肢 である。多真偽形式では選択肢のなかに複数個の正答 肢があり，Type 2 4 の上うに解答が選択肢の組合せ （解答コード群）で与えられている.

つぎに受験者側の知識の状態といら観点から検討す る. 正答肢を知っている状態を目，不正肢を知ってい る状態を区，選択肢が正答か誤りかわからない状態 
を?で印すことにすると，受験者の知識は口，区，?の 配列で表現できる。我々はこのQ，凶，?の配列を受験 者の『知識の状態』と名づけ。、日，，の配列は出 題形式による解答コードの構成の仕方によって限定さ れてくるため, 知識の状態は四，区，?のあらゆる組合 せをとるとは限らない。すなわち，知識の状態は出題 形式によって制約される。

多肢選択テストの出題形式が設定され，受験者の知 識の状態が与兄られると,未知な部分をランダム・ゲッ シングすることによって知識の状態に対する正答率が 得られる。

従来の単純ランダム・ダッシング・モデルでは確実 な知識をもっている場合と, 全く知らない場合の $2 つ$ の状態だけで構成されている、すなわち, 解答コード がM個ある場合，その知誠の状態に対応する正答率は 確実な知識で，すなわち確率 1 で正答するか，全く知 らないためあて推量で，すなわち確率 $1 / \mathrm{M} て ゙$ 正答する かのいずれかであったが，現実には確実な知識だけで はなく解答の一部分は知っているといら不十分な知識 の状態が想定される。このような不十分な知識を用い た，ランダム・ゲッシングに基づく正答率は， 1 か 1 / Mではなく，1，1/2,1/3，‥,1/Mをたは 0 となる。

\section{3. 知識の状態と正答率}

$\mathrm{M}$ 個の解答コードで構成されている多肢選択テスト を考光る。選択肢は $m$ 個あり，そのうち正答肢は $r$ 個 あるものとする、いま受験者がこのテストの $t$ 個の選 択肢について正答，愦り，不明の判断をしたとし，そ のらち $k$ 個の選択肢の正答または誤りの判断が正し くできたとする。㐬た正しく理解することができた $k$ 個の選択肢のうち, $j$ 個が正答肢， $(k-j)$ 個が不正肢 であったとする。このときこの受験者の知識の状態を, $S_{k j}(t)$ で表わし, この知識の状態の生起確率を $p_{k j}(t)$, この知識の状態にもとづく正答率を $q_{k j}$ とす る. $t$ を固定させたとき， $S_{k j}(t), p_{k j}(s)$ をそれぞれ $S_{k j}, p_{k j}$ と略記する。 $S_{k j}, p_{k j}, q_{k j}$ の関係を図 1 で示 寸.

不十分な知識の場合，未知な部分をランダム・ゲッ シングすることとする．正答率 $q_{k j}$ は $1 ， 1 / 2, \ldots$, $1 / i, \ldots, 1 / \mathrm{M}$ 及び 0 のいずれかの值をとるが, 正答 率 $q_{k j}$ が $1 / i$ となる知識の状態をとくに $S_{k j i}(t)$, 五た その生起確率を $p_{k j i}(t)$ とかくことにする。ここに $k=$ $0,1, \ldots, m ; j=0,1, \ldots, r ; i=1,2, \ldots, \mathrm{M}$ である. $i=1,2, \ldots, \mathrm{M}$ のと正答率 $1 / i$ の知識の状態の集

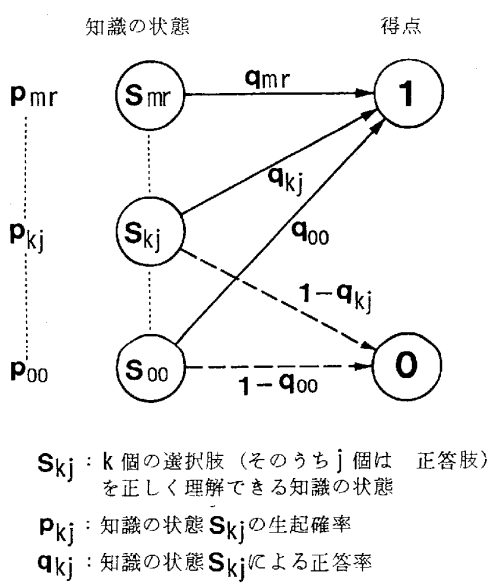

図 1. $\mathrm{m}$ 個の選択肢（そのうち $\mathrm{r}$ 個が正答肢）が与克 られたときの知識の状態と正答率

合を事象 $E_{i}, E_{j}$ の生起する確率を $\mathrm{P}_{i}(t)$ で表わすと, $\mathrm{P}_{i}(t)$ は正答率 $1 / i$ の知識の状態の生起確率の和で表 わされる。

$$
\mathrm{P}_{i}(t)=\sum_{k=0}^{m} \sum_{j=0}^{r} p_{k j i}(t)
$$

確率 1 で正答肢を誤りとみなす場合には, 誤判断に より必ず誤答するため, 正答率が 0 となる.正答率 0 の 知識の状態の集合を $E_{0}$ とし， $E_{0}$ の生起する確率を $\mathrm{P}_{0}(t)$ で表わす.

$\mathrm{P}_{i}(t)$ または $\mathrm{P}_{0}(t)$ は, 受験者が $t$ 個の選択肢につ いて, 正答, 誤り及び不明とわかったときの正答率 $1 /$ $i$ 末たは 0 で正解できる割合である. $\mathrm{P}_{i}(t)$ は出題され た問題数に対して, “正答率 $1 / i$ で正解でさる問題数の 割合，あるいは 1 つの問題に対して正答率 $1 / i$ で正解 できる受験者の割合とも考えられる。

このような確率の組 $\left(\mathrm{P}_{1}(t), \mathrm{P}_{2}(t), \ldots, \mathrm{P}_{\mathrm{M}}(t)\right.$, $\left.\mathrm{P}_{0}(t)\right)=\mathbf{P}(t)$ を考克, これを受験者の『正答率の分布』 と名づける。この正答率分布は, 受験者の知識の状態 の割合を記述したもので, $\mathrm{P}_{1}(t)$ は確実な知識の割合, $\mathrm{P}_{2}(t), \ldots, \mathrm{P}_{\mathrm{M}-1}(t)$ は不十分な知識の割合, $\mathrm{P}_{\mathrm{M}}(t)$ は 全く知識のなかった割合を示す。

従来の単純ランダム・ゲッシング・モデルをこの正 答率分布で表現すれば, $\mathrm{P}_{2}(t)=\cdots=\mathrm{P}_{\mathrm{M}-1}(t)=0$, $\mathrm{P}_{0}(t)=0$ すなわち

$$
\mathbf{P}^{*}=\left(\mathrm{P}_{1}(t), 0, \ldots, 0,1-\mathrm{P}_{1}(t), 0\right)
$$

となる。この意味からもこの正答率分布は単純ランダ ム・ダッシング・モデルを抬張したものとなっている. 
正答率の平均的な指標として

$$
\overline{\mathrm{P}}(t)=\sum_{i=1}^{\mathrm{M}}\left\{\mathrm{P}_{i}(t) / i\right\}
$$

を与える。 $\overline{\mathrm{P}}(t)$ は多肢選択テストに括ける平均正答率 を表わしている，単純ランダム・ゲッシング・モデル では

$$
\overline{\mathrm{P}}^{*}(t)=\mathrm{P}_{1}(t)+\left(1-\mathrm{P}_{1}(t)\right) / \mathrm{M}
$$

となる.

この正答率分布 $\mathbf{P}$ をった受験者に対して, $n$ 題出 題されたときの正答数の平均值及び分散を求める. 以 下の議論では $t$ を固定して考学る。

与えられた $n$ 問は互いに独立で, 各問は同じ正答率 分布 $\mathbf{P}$ をつものとする. 事象 $E_{i}$ に対して, 確率 $\mathrm{P}_{i}(t) / i$ で值 1 , 確率 $1-\mathrm{P}_{i}(t) / i$ で值 0 をとる確率変 数 $X_{i}(t)$ を導入する. $X_{i}(t)$ は $\mathrm{P}_{i}(t)$ による $n$ 問中の 正答数を表わす。 また組 $\left(X_{1}(t), X_{2}(t), \ldots, X_{\mathrm{M}}(t)\right)$ は項数 $n$, 確率 $\mathrm{P}_{i}(t) / i$ の多項分布に従う.

$$
X(t)=\sum_{i=1}^{\mathrm{M}} X_{i}(t)
$$

と打くと $X(t)$ は正答率分布 $\mathbf{P}$ とよる $n$ 問中の正答 数を表わす. 正答数 $X(t)$ の平均值 $\mathrm{E}(X(t))$ 及び分散 $\mathrm{V}(X(t))$ は次のようになる。

$$
\begin{aligned}
\mathrm{E}(X(t)) & =n \sum_{i=1}^{\mathrm{M}}\left(\mathrm{P}_{i}(t) / i\right)=n \overline{\mathrm{P}}(t) \\
\mathrm{V}(X(t)) & =n\left[\sum_{i=1}^{\mathrm{M}}\left(\mathrm{P}_{i}(t) / i\right)-\left\{\sum_{i=1}^{\mathrm{M}}\left(\mathrm{P}_{i}(t) / i\right)\right\}^{2}\right] \\
& =n \overline{\mathrm{P}}(t)(1-\overline{\mathrm{P}}(t))
\end{aligned}
$$

上の式より出題数 $n$ が一定のとき, 正答数 $X(t)$ の 分布は, 平均正答率 $\overline{\mathrm{P}}(t)$ のみによって特性づけられ る.

\section{4. 医師・歯科医師国家試験における出題形式と知 識の状態}

まず最近の医師・歯科医師国家試験に採用されてい る出題形式 (Type 1 5) の性質について検討する. 正 答肢の数は Type 1,2,3 ではそれぞれ，1 個，2 個，3 個となっている.また Type 4 の正答肢の数は 1, 2, 3, 4 のいずれかとなって打り, Type 5 は, Type 1 の変形 ではあるが，1正解形式にさらに正答肢がない場合が 混合されている. Type 1，2，3では正解コードがa， b， . . , e のいずれでも正答肢の数は変わらないが, Type 4, 5 では正解コードの位置によって正答肢の数 が異なる。

一方，選択肢(1), (2)， . . ., (5) を循環させて考光ると，
Type 2 では 2 個の正答肢が連に, Type 3 については 3 個の正答肢が連になって解答コードを形成してい る. Type 4 では解答コード d では正答肢が 1 個, a, b では 2 個， c では 3 個，eでは 4 個の連を形成してい る. この連に着目して, 我々は Type 1, 2,3,4 をそれ ぞれ単一式, 二連式, 三連式, 複合連式と名づける。 た Type 5 を単一変形式と名づける，正答肢だけでな く不正答肢の連にも着目して考学ると正答肢が 1 個の 場合は不正肢の 4 連, 正答肢がない場合は不正肢の 5 連と考兄られるから，これらの出題形式はすべての解 答コードが正答肢または不正肢の連を形成していると いえる.

次に, これら 5 つの出題形式のらち, ここでは単一 式と二連式をとりあげ，とりらる知識の状態とその正 答率を求める. 出題形式によっては, 選択肢の正答, 不 正の理解及び不明の個数が同じでも，その配列によっ て，正答率が異なる場合が生じるので，正答率が異な る場合には回, 凶, ? の配列までを考慮して知識の状態 を細分化した， $m=t=5$ すなわち 5 個の選択肢が与光 られ，受験者が 5 個の選択肢のすべてについて，その 正答, 誤り, 不明の判断を得た後の知識の状態と正答 率を, 単一式については表 1 で, 二連式については表 2 で示した。 (表 1,2 では $t=5$ のため記号 $S_{k j}(5)$ をす べて $S_{k j}$ で略記した.）

表 1,2 より, 二連式に抢ける知識の状態の正答率 は, 単一式のそれに比して次の点で著しく異なってい ることがわかる。

表 1 . 単一式による知識の状態と正答率

\begin{tabular}{c|l|c|l}
\hline \multicolumn{2}{c|}{ 知識の状態 } & 正答率 & $\begin{array}{c}\text { 二項モデルによる } \\
\text { 生起確率 }\end{array}$ \\
\hline$S_{\cdot_{1}}$ & ○ & 1 & $p$ \\
\hline$S_{40}$ & $? \times \times \times \times$ & 1 & ${ }_{4} C_{0}(1-p) q^{4}$ \\
\hline$S_{30}$ & ? ? $\times \times \times$ & $\frac{1}{2}$ & ${ }_{4} C_{1}(1-p) q^{3}(1-q)$ \\
\hline$S_{20}$ & ? ? ? $\times \times$ & $\frac{1}{3}$ & ${ }_{4} C_{2}(1-p) q^{2}(1-q)^{2}$ \\
\hline$S_{10}$ & ? ? ? ? $\times$ & $\frac{1}{4}$ & ${ }_{4} C_{3}(1-p) q(1-q)^{3}$ \\
\hline$S_{00}$ & ? ? ? ? ? & $\frac{1}{5}$ & ${ }_{4} C_{4}(1-p)(1-q)^{4}$ \\
\hline
\end{tabular}

（注） $S_{51}, S_{41}, S_{31}, S_{21}, S_{11}$ はすべて 1 個の正答肢を 知っているため, これらをまとめて $S_{11}$ とした 
表 2.2 連式による知識の状態と正答率

\begin{tabular}{|c|c|c|c|}
\hline \multicolumn{2}{|c|}{ 知識の状態 } & 正答率 & $\begin{array}{c}\text { 二項モデルによる } \\
\text { 生起確率 }\end{array}$ \\
\hline$S_{\cdot 2}$ & 00 & 1 & $p^{2}$ \\
\hline$S_{41}$ & $? 0 \times \times \times$ & 1 & $2(1-p) p q^{3}$ \\
\hline$S_{31}$ & $? \bigcirc \times \times ?$ & 1 & $2(1-p) p q^{2}(1-q)$ \\
\hline$S_{31 "}$ & $? \bigcirc \times ? \times$ & 1 & $2(1-p) p q^{2}(1-q)$ \\
\hline$S_{31^{\prime \prime \prime}}$ & $? 0 ? \times \times$ & $\frac{1}{2}$ & $2(1-p) p q^{2}(1-q)$ \\
\hline$S_{30}$ & $? ? \times \times \times$ & 1 & $(1-p)^{2} q^{3}$ \\
\hline$S_{21}$ & $? \bigcirc \times ? ?$ & 1 & $2(1-p) p q(1-q)^{2}$ \\
\hline$S_{21^{\prime \prime}}$ & $? \bigcirc ? \times ?$ & $\frac{1}{2}$ & $4(1-p) p q(1-q)^{2}$ \\
\hline$S_{20^{\prime}}$ & $? ? \times \times ?$ & $\frac{1}{2}$ & $2(1-p)^{2} q^{2}(1-q)$ \\
\hline$S_{20^{\prime \prime}}$ & $? ? \times ? \times$ & 1 & $(1-p)^{2} q^{2}(1-q)$ \\
\hline$S_{11}$ & ? ? ? ? & $\frac{1}{2}$ & $2(1-p) p(1-q)^{3}$ \\
\hline$S_{10}$ & ? ? × ? & $\frac{1}{3}$ & $3(1-p)^{2} q(1-q)^{2}$ \\
\hline$S_{00}$ & ?? ? ? ? & $\frac{1}{5}$ & $(1-p)^{2}(1-q)^{3}$ \\
\hline
\end{tabular}

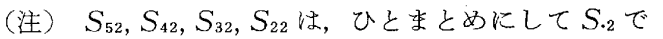
示した

（1）各選択肢の正答，誤り，不明の知識に出題形式 の連の規則性の情報が加わると,正答率は上昇する。換 言すれば一部分の知識でも解答コードの規則性を知る ことにより確率 1 で正答できる場合が生ずる、たと党 ば, 単一式では一つの正答肢を見つけること以外に, 他 の 4 つの不正肢を知ることにより確率 1 で正答するこ とができる。二連式では，状態（？四？？）で正答 率 1 となる.

（2）単一式では理解した選択肢の数が多ければ多い ほど正答率は高くなるのに較べて，二連式では，理解 した選択肢の数が多くても，理解した選択肢の数が少 ない知識の状態よりも正答率が低くなることがある. たと壳ば表 2 の状態 $S_{31}{ }^{\prime \prime}$ (1 個の正答肢と 2 個の不正 肢計 3 個の選択肢を知っている) は, 状態 $S_{20}{ }^{\prime \prime}$ (2 個の 不正肢を知っている）よりも正答率は低い。つまり理 解している選択肢の個数が多いにもかかわらず正答率 は逆転している。

(3) 単一式では日, 区，?の個数が同じであれば正答 率は変わらないが, 二連式では, 区, ?の個数が同じ
でむ，その配列によって正答率が異なる場合が生ずる。 たと竞 2 の $S_{31}{ }^{\prime}, S_{31}{ }^{\prime \prime}, S_{31}{ }^{\prime \prime \prime}$ はQ，区，?の個数は 同じであるが， ○，区，?の配列によって正答率がそれ ぞれ $1,1,1 / 3$ と異なっている。束た $S_{31}{ }^{\prime \prime \prime}, S_{21}{ }^{\prime \prime}$, $S_{11} \cdots ; S_{20}{ }^{\prime}$ は, , 区, ? の個数が異なっているが正答 率は同じである。

二連式に拉ける知識の状態とそれに伴ら正答率が特 異な性質を示すひとつの要因は，二連式が与えられた 5 個の選択肢のなかで, 正答肢がランダムに 2 個配置 されているのではなく，正答肢が連になっているから である、換言すれば，二連式の選択肢は 2 連の正答肢 (○群) と 3 連の不正肢 ( $\times$ 群) から成りたっているた め, 二連式での解答コードは，ただ単に 5 個の選択肢 のららから正答肢を 2 個指定しているのではなく，選 択肢を○群と×群の 2 群にわけていることである。こ の意味からも二連式の問題は○群と×群の境界を見き わめる問題ともい方る。

\section{5. 知識の状態の生起確率}

選択肢数を 5, 小わゆる 5 肢選択とし, 出題形式を単 一式と二連式に限定し, 知識の状態の生起確率を, 正 答肢，不正肢をそれぞれ正答，䛊りと正しくわかる割 合とそれらの配列によって構成する。

正答肢，不正肢について，それを受験者が正答，誤 りあるいはわからない（不明）と判断するかによって 次の 6 通りが考学られる.

正答肢について（正答，誤り，不明）

不正肢について（正答，誤り，不明）

上の 6 通りの場合について, 受験者のとりらる割合を 次のように書くことにする.すなわち正答肢について は左から順に $p_{1}(\bigcirc), p_{2}(\bigcirc), p_{3}(\bigcirc)$, 不正肢について は $q_{1}(\times), q_{2}(\times), q_{3}(\times)$ とする。

このとき $i=1,2,3 ; j=1,2,3$ に対して

$0 \leqslant p_{i}(\bigcirc) \leqslant 1, \quad 0 \leqslant q_{j}(\times) \leqslant 1$

かつ

$\sum_{i=1}^{3} p_{i}(\bigcirc)=1, \quad \sum_{j=1}^{3} q_{j}(\times)=1$

ここでは議論をかんたんにするため, 誤判断をしな い場合すなわち $p_{2}(\bigcirc)=0, q_{1}(\times)=0$ について考㐫 る。したがって受験者は選択肢を正しく理解し, 正答 肢を正答あるいは不正肢を不正とするか，あるいは正 しく理解できないため不明とみなすかのいずれであ る。すなわち正答肢は正答か不明，不正肢は不正か不 明のいずれかに判断されるものとする。

正答肢を正答と正しく理解できる確率 $p_{1}(\bigcirc)$ をあ 
らためて $q_{2}(\times)$ を $q$ とする. 不明となる確率は正答肢では 1 $p$, 不正肢では $1-q$ となる。

知識の状態の生起確率の構成方法として次の (i), (ii)の方法が考党る.

（i）与兄られた選択肢のすべてについて，各選択 肢を正答，誤りか不明かに判定する。各選択肢は互い に独立に理解できるものとする。これらの仮定のもと に, 正答, 誤り, 不明のとりらる順列を考光, その生 起確率を算出する方法。

（ii）選択肢を 1 個ずつ選定し，その判定によって 次に判定すべき選択肢を選ぶ。るたそれ以上の情報を 得ても正答率が上昇しない知識の状態に達したとき, 選択肢の選定と判定を停止する。このような解答方式 に従って，日，日，?の配列に重点を置いた生起確率を 算出する方法.

我々は（i ）を生起確率の「2 項モデル」，(ii）を「ター ミナル・モデル」と呼ぶことにする。次に(i ), (ii) の方法で単一式, 二連式について知識の状態の生起確 率を求める.

i ) 2 項モデル

2 項モデルは次の前提に基づいて構成されている.

（1）各選択肢は，それが理解できるか，理解できな いかのいずれかの判定しかできない。すなわち正答肢 は正答か不明に, 不正肢は誤りか不明かに判定される。

(2) 正答肢の理解できる確率はどの正答肢について も同一である。選択肢の判定は互いに独立に，から与 えられたすべての選択肢について行われる，換言すれ ば 2 項モデルは，5個の選択肢全部について，その正 答, 誤り, 不明の判定を得た場合の生起確率を与兄る。

ここでは 2 項モデルによる生起確率の算出の一例と して，知識の状態（？？？冈日）の 2 項モデルによる 生起確率を単一式と二連式について求めてみよう。

1. 単一式 単一式での知識の状態(??? ? 区回)で の????に対応する選択肢は本来不正肢である。 3 個 の不正肢が理解できず 1 個の不正肢と正答肢を正しく 理解できる確率は $(1-q)^{3} p q$ となるからこの確率にと りらる場合の数を乗じると, 求める生起確率は ${ }_{4} C_{1}(1-q)^{3} p q$ となる.

状態(？？？凶团)は $S_{21}$ と表示できるが，同様にし $\tau, S_{51}, S_{41}, S_{31}, S_{11}$ などの状態 $S_{t+11}(l=0,1,2,3$, 4) の生起確率は，それぞれ

$$
{ }_{4} C_{l}(1-q)^{l} q^{4-l} q
$$

となる. $S_{51}, S_{41}, S_{31}, S_{21}, S_{11}$ はすべて 1 個の正答肢
を知っている状態であるから，これらをひとまとめに して S.1 で表わすと, S.1 の生起確率は

$$
\sum_{l=0}^{4}{ }_{4} C_{l}(1-q)^{l} q^{4-l} p=p
$$

となる。

同様にして，他の知識の状態の生起確率も算出でさ る. 単一式に括ける 2 項モデルによる生起確率は表 1 で示される.

2. 二連式二連式の規則性により知識の状態 (??? ?凶团)の最初の? は本来正答肢, 残りの? ? は 不正肢であるから, 3 個の ? 之 1 個の凶, 1 個の回を得 る確率は $(1-p)(1-q)^{2} p q$ となる。またこの上うな配 列のとりらる場合の数は 5 通りあるから, 求める生起 確率は $5(1-p)(1-q)^{2} p q$ となる. 他の知識の状態の 生起確率も二連式の規則性を考慮することにより同様 にして求められる。二連式に扮ける 2 項モデルの生起 確率は表 2 で示される。

また 2 項モデルによる，単一式，二連式に㧤ける平 均正答率をそれぞれ $\bar{P}_{s}, \bar{P}_{w}$ とすると, $\bar{P}_{s}, \bar{P}_{w}$ は次 のよらになる。

$$
\begin{gathered}
\bar{P}_{s}=p+\frac{1}{5}(1-p)\left(1+q+q^{2}+q^{3}+q^{4}\right) \\
\begin{aligned}
\bar{P}_{w} & =p+(1-p) q+\frac{1}{5}(1-p)^{2}(1-q)^{3} \\
\bar{P}_{s}-\bar{P}_{w} & =\frac{(1-p)(1-q)}{5}\left\{(1-q)^{2} p\right. \\
& \left.-q(1-q)^{2}-5 q^{2}\right\} \\
& =\frac{(1-p)(1-q)^{3}}{5}\left[p-\left\{q+5\left(\frac{q}{1-q}\right)^{2}\right\}\right] \\
& (q \neq 1)
\end{aligned} \\
0<p<1,0<q<1 \text { のとき } \bar{P}_{s}>\bar{P}_{w} \text { となるのは } \\
q+5\left(\frac{q}{1-q}\right)^{2}<1
\end{gathered}
$$

を満足する $q$ に対して

$$
p>q+5\left(\frac{q}{1-q}\right)^{2}
$$

を満足する $p$ が存在するときである。式 (5.6) を数值 計算で解くと $q<0.275$ を得る.

(ii) ターミナル・モデル

2 項モデルは 5 肢全部について, その正答, 誤り, 不 明を見いだしたときの知識の状態の生起確率である が, 一方目， 区，?の得られる順序とその配列が知識の 状態を特徵づける場合には，目，区，?の得られる順序 と配列に注目した知識の状態の生起確率を構成しなけ ればならない。 
ここでは選択肢を 1 個ずつ選んでゆく次のよらな解 答方式を考光る.1つの選択肢の正答, 誤り，不明の判 定の後, 得られた知識の状態から次の判定すべき選択 肢をさめる。またそれ以上の選択肢の正答，誤りなど を知っても正答率が上昇しないことがわかったとき， 次の選択肢の選定を停止し，その知識の状態で正解 コードを判断する.またこのときの知識の状態を「ター ミナル」と呼ぶことにする。このような解答ルールに 従うと, 知識の状態分, 選択肢の判定 $(\square, 区, ?) に$ よっていろいろな知識の状態に推移し，これ以上の情 報を得ても正答率が上昇しない知識の状態，すなわち ターミナルに至って，その推移は停止する．このこと から，我々はこのモデルを「ターミナル・モデル」と 名づけた。

単一式では，1個の正答肢をさぐりあてることにあ るから，党らばれた選択肢の判定が四以外であれば次 の選択肢以外の選択肢をランダムに選ぶことになる。 これに対して二連式では, 正答肢が連になって解答 コードが規則性をもっているため, その思考パターン は複雑なものになっている。

選択肢の選ばれてゆく順に，それらを第 1 肢，第 2 肢, ..., 第 5 肢と名づけ，単一式，二連式について次 のような解答ルールを設定する。

(1) 単一式での解答ルール

(1) ランダムに第 1 肢をえらぶ. 第 1 肢の判定がロ ならば，それ以降の選択肢の判定を停止する。

(2) 第 1 肢がす以外であれば，第 2 肢は第 1 肢以外 の選択肢をランダムにとって良いるのとする，以下こ の思考パターンをくり返す。

単一式に和ける第 5 肢以前のターミナルは第 1 肢, 第 2 肢, ..., 第 4 肢に田位置する知識の状態と第 1 肢から第 4 肢まですべて困の状態である.

(2) 2 連式での解答ルール

(1) 第1肢はランダムに選ぶ.

(2) 第 2 肢はか冈ならば，第 2 肢はその僢接の選 択肢の一方を選ぶ。

(3) 第 3 肢以降での，凶の隣接する選択肢のえらび 方の優先順位は, Qの隣接, 凶の隣接, ?の隣接の順と する.

(4) 第 1 肢が ?ならば，第 2 肢を第 1 肢以外の選択 肢をランダムに選ぶ。

(5) 5 肢全部を判定する途中に日，区，?の配列の一 部が次のパターンになったとき，次の選択肢をえらぶ ことをやめ，その知識の状態で正解コードを決める.
（知識が不十分な場合はランダム・ゲッシングを行う.）

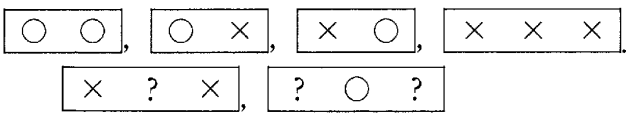

ターミナル・モデルに捛ける知識の状態の推移を単 一式については図 2, 二連式については図 3で示す。

ターミナル・モデルによる $t$ 肢亲での状態は，1個， 2 個,...,$(t-1)$ 個のQ，区，?でできるターミナル の状態と， $t$ 個の曰，区，?でできる状態から成りたっ ている. 1 個, 2 個, $\ldots, t$ 個の日，区，?でできる状態 の生起確率は正答肢,不正肢のとりだされる確率と正 答, 誤り, 不明の確率によって構成されるものとする. 選択肢のとり出されかたは, 単一式では一つの正答肢 を見い出すまでは任意に選んで良いものとし，二連式 では第 1 肢を任意に選び，第 2 肢次降は隣接方式とす る。また与兄られた正答，不正肢はそれぞれ等確率で とりだされるものとし，正答肢，不正肢の理解できる 確率は 2 項モデルと同様にそれぞれ $p, q$ とする。

（a）第1肢から第5 肢までの経路

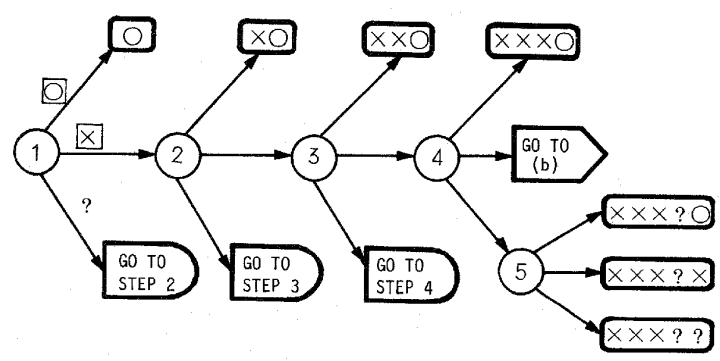

(b) 第 4 肢における区後の経路

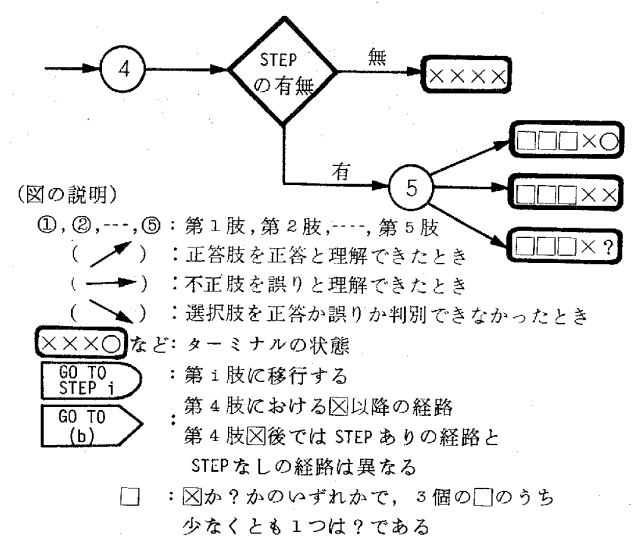

図2．単一式に和けるターミナル・モデル 


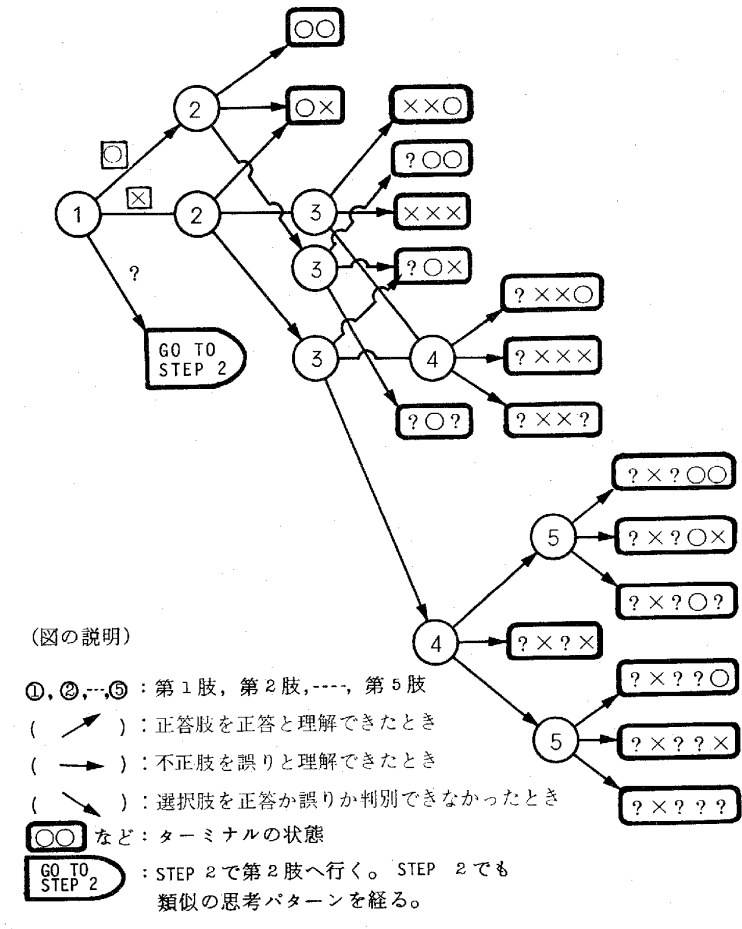

図3.2 連式に括けるターミナル・モデル

第 1 肢が区で第 2 肢がの状態（メ○）を例にとっ て単一式と 2 連式についてターミナル・モデルによる 生起確率を求めよう.

(1) 単一式

単一式で第 1 肢に不正肢が，第 2 肢に正答肢がとり だされる確率は $1 / 5$ となるから，第 1 肢区，第 2 肢 の状態の生起確率は $p q / 5$ となる。

(2) 二連式

二連式で第 1 肢に不正肢がとりだされるのは $3 / 5$, 不正肢の隣りに正答肢がとりだされる確率は $1 / 3$ であ る. 第 1 肢区, 第 2 肢目となる確率は $1 / 5$ となるから, この生起確率は $p q / 5$ となる。

二連式に扔いては, 第 1 肢曰, 第 2 肢凶も状態（× ○)を構成し,この場合の生起確率は同様な推論によっ て $p q / 5$ となり前に求めた生起確率と一致する。 二連 式に抢いて状態 $(\times \bigcirc)$ の生起確率は $2 p q / 5$ となる。他 の知識の状態についてもターミナル・モデルによる生 起確率を求めることができる.

ターミナル・モデルに㧍ける第 $t$ 肢で得られたひと つの知識の状態を $S_{j}(t)$ とすると, 第 $(t+1)$ 肢でのあ る知識の状態 $S_{k}(t+1)$ の生起確率 $P\left(S_{k}(t+1)\right)$ は $t$
肢に招ける生起確率 $P\left(S_{j}(t)\right)$ と $t$ 肢での状態 $S_{j}(t)$ 加ら $(t+1)$ 肢での状態 $S_{k}(t+1)$ への遷移確率 $P\left(S_{k}(t+1) \mid S_{j}(t)\right)$ 火よって表現することもでさる.

$$
\begin{aligned}
P\left(S_{k}(t+1)\right)= & \sum_{j} P\left(S_{j}(t)\right) \\
& \times P\left(S_{k}(t+1) \mid S_{j}(t)\right)
\end{aligned}
$$

したがって, ターミナル・モデルの知識の状態の生起 確率は, 図2, 図 3 にもとづいて第 1 肢での知識の状態 の生起確率より出発して, 順次, 第 2 肢, 第 3 肢, ..., 第 5 肢までの知識の状態の生起確率を求めることもで きる。

単一式，二連式に和ける第 1 肢，第 2 肢まで，... 第 5 肢までに得られる知識の状態の生起確率はそれぞ れ表 $3 ， 4$ で示される.

また, 単一式と二連式に拈いて, $p=q=0.5$ の場合の 正答率分布之平均正答率を求め, それらを 2 項モデル

表 3. ターミナル・モデルによる生起確率(単一式)

（1） 1 肢による知識の状態

\begin{tabular}{|c|c|c|}
\hline 知識の状態 & 正答率 & 生 起 確 率 \\
\hline 0 & 1 & $\frac{1}{5} p$ \\
\hline$\times 0$ & 1 & $\frac{1}{5} p q$ \\
\hline$? \bigcirc$ & 1 & $\frac{1}{5} p(1-q)$ \\
\hline$x \times$ & $\frac{1}{3}$ & $\frac{3}{5} q^{2}$ \\
\hline$\times ?$ & $\frac{1}{4}$ & $2\left\{\frac{1}{5} q(1-p)+\frac{3}{5} q(1-q)\right\}$ \\
\hline ? ? & $\frac{1}{5}$ & $\frac{2}{5}(1-p)(1-q)+\frac{3}{5}(1-q)^{2}$ \\
\hline \multicolumn{2}{|l|}{ 計 } & 1 \\
\hline
\end{tabular}

\begin{tabular}{c|c|l}
\hline 知識の状態 & 正答率 & \multicolumn{1}{|c}{ 生起 確率 } \\
\hline 0 & 1 & $\frac{1}{5} p$ \\
\hline$\times$ & $\frac{1}{4}$ & $\frac{4}{5} q$ \\
\hline$?$ & $\frac{1}{5}$ & $\frac{1}{5}(1-p)+\frac{4}{5}(1-q)$ \\
\hline \multicolumn{2}{c|}{} & 1 \\
\hline \multicolumn{2}{c|}{ 計 }
\end{tabular}


(3) 3 肢变での知識の状態

\begin{tabular}{c|c|l}
\hline 知識の状態 & 正答率 & \multicolumn{1}{|c}{ 生起 確 率 } \\
\hline$\bigcirc$ & 1 & $\frac{1}{5} p$ \\
\hline$\times \bigcirc$ & 1 & $\frac{1}{5} p q$ \\
\hline$? \bigcirc$ & 1 & $\frac{1}{5} p(1-q)$ \\
\hline$\times \times \bigcirc$ & 1 & $\frac{1}{5} p q^{2}$ \\
\hline$\times ? \bigcirc$ & 1 & $2\left\{\frac{1}{5} p q(1-q)\right\}$ \\
\hline ? ? & 1 & $\frac{1}{5} p(1-q)^{2}$ \\
\hline$\times \times \times$ & $\frac{1}{2}$ & $\frac{2}{5} q^{3}$ \\
\hline$\times \times ?$ & $\frac{1}{3}$ & $3\left\{\frac{1}{5}(1-p) q^{2}+\frac{2}{5} q^{2}(1-q)\right\}$ \\
\hline$? ? \times$ & $\frac{1}{4}$ & $3\left\{\frac{2}{5}(1-p) q(1-q)\right.$ \\
\hline$\left.? ? \frac{2}{5} q(1-q)^{2}\right\}$ \\
\hline
\end{tabular}

については表 5,ターミナル・モデルについては表 6 で 示した.

\section{6. 考 察}

1）提案した二項モデルとターミナル・モデルは,多 肢選択テストに拈ける受験者の不十分な知識の度合い を記述するための数学モデルである。それらのモデル に基ついて, 不十分な知識を含めた，受験者のとりら る知識の状態の生起確率を算出し, その正答率分布を 求めた。

従来の単純ランダム・ゲッシング・モデルでは正答 率が 1 か $1 / \mathrm{M}$ に限定されていたが，これらのモデル による正答率は表 5,6 です示されるよ5に, 正答率 1 , 1/M のほかにあらたに正答率 $1 / 2,1 / 3, \ldots, 1 /(\mathrm{M}$ -1) 方導入され，その正答率分布が求められて和り, 従来のランダム・ゲッシング・モデルを拡張したもの になっている。

2） 2 項モデルとターミナル・モデルを比較する.
2 項モデルは与えられた選択肢のすべてについて判 断を得た後の正答率分布や平均正答率を与兄る。ター ミナル・モデルは判定された選択肢数に応じて, 正答 率分布や平均正答率の推移を示す。

ターミナル・モデルは 2 項モデルに較べて, 次のよ らな利点を持っている。

(1) 単一式で状態（？×○）での？の選択肢は不正

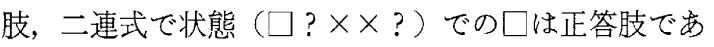
ることがわかる。このよらに 5 肢以前のある知識の状 態で, 既に得た一部の知識を使って, 他の選択肢の正 答，誤りを推測することもでさる。

(2) 二連式での状態（？○？）では，他の選択肢の 情報を加えても正答率は $1 / 2$ から上昇しない。このよ らなターミナルは，ある知識の状態で選択肢の判定を 停止し，その状態で正解コードを決定させるある種の 解答ルールが存在することを示唆する。この解答ルー ルを使用することによって，解答時間を短縮すること もできるであろら。

3) $p=q=0.5$ の場合の正答率分布と平均正答率に ついて考察する。 $p \neq 0$ だから $\mathrm{P}_{0}=0$ となるため正答率 分布を $\mathbf{P}=\left(\mathrm{P}_{1}, \mathrm{P}_{2}, \mathrm{P}_{3}, \mathrm{P}_{4}, \mathrm{P}_{5}\right)$ とすると, 表 5 より単 一式では, 2 項モデル, ターミナル・モデルによる正答 率分布はともに $\mathrm{P}_{1}-0.5<\mathrm{P}_{2}<\mathrm{P}_{3} ; \mathrm{P}_{3}>\mathrm{P}_{4}>\mathrm{P}_{5}$ とな り, 正答率分布 $\mathbf{P}$ は確実な知識に 2 項型の分布が加 わったものになっている。

これに対して表 6 より, 二連式では 2 項モデル,ター ミナル・モデルいずれに和いても $\mathrm{P}_{4}=0$ となってい る. また 2 項モデルと, ターミナル・モデルの 3 肢以 後では, $\mathrm{P}_{1}>\mathrm{P}_{2}>\mathrm{P}_{3}>\mathrm{P}_{5}$ の指数型に類似した様相を呈 している。

2 項モデルによる正答率分布とターミナル・モデル の 5 肢までの知識によるそれとは一致する。したがっ てターミナル・モデルでは 5 肢以前の情報がもたらす 正答率分布や平均正答率に意味がある。

表 6 より二連式のターミナル・モデルでは，2 肢から 3 肢にかけて平均正答率の大巾な增加がタられる。 た表 5,6 から平均正答率が 0.6 以上となるのは，単一 式では 4 肢以上となる.あらい見方をすれば， $p=q=$ 0.5 の場合, 6 割以上の平均正答率を得るには単一式で は 4 肢の， 2 連式では 3 肢以上の選択肢の判定が必要 である。

4）平均正答率と難易度について考察する

表 5,6 より $p=q=0.5$ の場合, 2 項モデル, ター ナル・モデルのいずれの場合にも, 二連式の方が単一 
（4）４肢までの知識の状態

\begin{tabular}{|c|c|c|}
\hline 知識の状態 & 正答率 & 生 起 確 率 \\
\hline$\bigcirc$ & 1 & $\frac{1}{5} p$ \\
\hline$\times 0$ & 1 & $\frac{1}{5} p q$ \\
\hline$? \bigcirc$ & 1 & $\frac{1}{5} p(1-q)$ \\
\hline$\times \times 0$ & 1 & $\frac{1}{5} p q^{2}$ \\
\hline$\times ? 0$ & 1 & $\frac{2}{5} p q(1-q)$ \\
\hline$? ? \bigcirc$ & 1 & $\frac{1}{5} p(1-q)^{2}$ \\
\hline$\times \times \times 0$ & 1 & $\frac{1}{5} p q^{3}$ \\
\hline$\times \times ? \bigcirc$ & 1 & $3\left\{\frac{1}{5} p q^{2}(1-q)\right\}$ \\
\hline x?? ? & 1 & $3\left\{\frac{1}{5} p q(1-q)^{2}\right\}$ \\
\hline ?? ? $\bigcirc$ & 1 & $\frac{1}{5} p(1-q)^{3}$ \\
\hline$\times \times \times \times$ & 1 & $\frac{1}{5} q^{4}$ \\
\hline$\times \times \times ?$ & $\frac{1}{2}$ & $4\left\{\frac{1}{5} q^{3}(1-p)+\frac{1}{5} q^{3}(1-q)\right\}$ \\
\hline$\times \times$ ? ? & $\frac{1}{3}$ & $\begin{array}{l}6\left\{\frac{1}{5} q^{2}(1-p)(1-q)+\frac{1}{5} q^{2}(1-q)(1-p)\right. \\
\left.\quad+\frac{1}{5} q^{2}(1-q)^{2}\right\}\end{array}$ \\
\hline x ? ? ? & $\frac{1}{4}$ & $4\left\{\frac{3}{5} q(1-p)(1-q)^{2}+\frac{1}{5} q(1-q)^{3}\right\}$ \\
\hline ? ? ? ? & $\frac{1}{5}$ & $\frac{4}{5}(1-p)(1-q)^{3}+\frac{1}{5}(1-q)^{4}$ \\
\hline \multicolumn{2}{|c|}{ 計 } & 1 \\
\hline
\end{tabular}

（5） 5 肢までの知識の状態の生起確率は，2 項モデルのそれと類似のものとな る。

式より高い平均正答率を示している。

2 項モデルの平均正答率についても, $0<p<1, p=$ $q$ の場合, 式 $(5.5)$ より $\bar{P}_{s}<\bar{P}_{w}$ となり, 二連式の平 均正答率は単一式のそれより高いことが示される。 $p$ $=q$ の場合, 正答肢と不正肢の理解できる確率は等し いから, 結局与兄られた 5 個の選択肢の理解できる確
率はすべて等しい場合に相当する，5肢の5ち正選択 肢の含まれる割合は単一式では $1 / 5$, 二連式では $2 / 5$ であるが，二連式の平均正答率が高いことはひとつに はこの正答肢数に起因しているものと思われる.

表 5,6より単一式の平均正答率は二連式よりも低い 值を示している.このことからすぐに単一式の方が二 
表 4.ターミナル・モデルによる生起確率 ( 2 連式) (1) 1 肢による知識の状態

\begin{tabular}{c|c|l}
\hline 知識の状態 & 正答率 & \multicolumn{1}{|c}{ 生 起 確 率 } \\
\hline$\bigcirc$ & $\frac{1}{2}$ & $\frac{2}{5} p$ \\
\hline$\times$ & $\frac{1}{3}$ & $\frac{3}{5} q$ \\
\hline$?$ & $\frac{1}{5}$ & $\frac{2}{5}(1-q)+\frac{3}{5}(1-q)$ \\
\hline \multicolumn{2}{|c|}{ 計 } & 1 \\
\hline
\end{tabular}

(2) 2 肢までの知識の状態

\begin{tabular}{c|c|l}
\hline 知識の状態 & 正答率 & \multicolumn{1}{|c}{ 生起 確率 } \\
\hline$\bigcirc \bigcirc$ & 1 & $\frac{1}{5} p^{2}$ \\
\hline$\bigcirc \times$ & 1 & $2\left(\frac{1}{5} p q\right)$ \\
\hline$\bigcirc ?$ & $\frac{1}{2}$ & $2\left\{\frac{1}{5} p(1-p)+\frac{1}{5} p(1-q)\right\}$ \\
\hline$\times \times$ & $\frac{1}{2}$ & $2\left(\frac{2}{5} q^{2}\right)$ \\
\hline$\times ?$ & $\frac{1}{3}$ & $2\left\{\frac{1}{5} q(1-p)+\frac{2}{5} q(1-q)\right\}$ \\
\hline$? ?$ & $\frac{1}{5}$ & $\frac{1}{5}(1-p)^{2}+\frac{2}{5}(1-p)(1-q)$ \\
\hline & & 1 \\
\hline 竐 & & 1 \\
\hline
\end{tabular}

（3） 3 肢までの知識の状態

\begin{tabular}{|c|c|c|}
\hline 知識の状態 & 正答率 & 生 起確 率 \\
\hline 00 & 1 & $\frac{1}{5} p^{2}$ \\
\hline$O \times$ & 1 & $\frac{1}{5} p q$ \\
\hline$\times 0$ & 1 & $\frac{1}{5} p q$ \\
\hline$\times \times 0$ & 1 & $\frac{1}{5} p q^{2}$ \\
\hline$? 00$ & 1 & $2\left\{\frac{1}{5} p^{2}(1-q)\right\}$ \\
\hline$? \bigcirc \times$ & 1 & $4\left\{\frac{1}{5} p q(1-p)\right\}$ \\
\hline$x \times x$ & 1 & $\frac{1}{5} q^{3}$ \\
\hline$? \bigcirc ?$ & $\frac{1}{2}$ & $2\left\{\frac{2}{5} p(1-p)(1-q)\right\}$ \\
\hline$\times \times ?$ & $\frac{1}{2}$ & $3\left\{\frac{1}{5} q^{2}(1-p)+\frac{1}{5} q^{2}(1-q)\right\}$ \\
\hline$? ? 0$ & $\frac{1}{2}$ & $\frac{1}{5} p(1-p)(1-q)+\frac{1}{5} p(1-q)^{2}$ \\
\hline$? \times ?$ & $\frac{1}{3}$ & $2\left\{\frac{2}{5} q(1-p)(1-q)+\frac{1}{5} q(1-q)^{2}\right\}$ \\
\hline ? ? X & $\frac{1}{3}$ & $\frac{1}{5} q(1-p)^{2}+\frac{1}{5} q(1-p)(1-q)+\frac{1}{5} q(1-q)^{2}$ \\
\hline ?? ? & $\frac{1}{5}$ & $\begin{array}{l}\frac{2}{5}(1-p)^{2}(1-q)+\frac{2}{5}(1-p)(1-q)^{2} \\
\quad+\frac{1}{5}(1-q)^{3}\end{array}$ \\
\hline \multicolumn{2}{|c|}{ 計 } & 1 \\
\hline
\end{tabular}


（4）４肢までの知識の状態

\begin{tabular}{|c|c|c|}
\hline 知識の状態 & 正答率 & 生 起 確 率 \\
\hline 00 & 1 & $\frac{1}{5} p^{2}$ \\
\hline$O x$ & 1 & $\frac{1}{5} p q$ \\
\hline$\times 0$ & 1 & $\frac{1}{5} p q$ \\
\hline$? 00$ & 1 & $2\left\{\frac{1}{5} p^{2}(1-q)\right\}$ \\
\hline$? \bigcirc \times$ & 1 & $2\left\{\frac{1}{5} p q(1-p)\right\}$ \\
\hline$? \times \bigcirc$ & 1 & $2\left\{\frac{1}{5} p q(1-q)\right\}$ \\
\hline$\times \times 0$ & 1 & $\frac{1}{5} p q^{2}$ \\
\hline$x \times x$ & 1 & $\frac{1}{5} q^{3}$ \\
\hline$? \bigcirc ?$ & $\frac{1}{2}$ & $2\left\{\frac{2}{5} p(1-p)(1-q)\right\}$ \\
\hline$O \times \times ?$ & 1 & $3\left\{\frac{1}{5} p q^{2}(1-q)\right\}$ \\
\hline$\times \times \times ?$ & 1 & $3\left\{\frac{1}{5}(1-p) q^{3}\right\}$ \\
\hline$? \times ? \times$ & 1 & $2\left\{\frac{1}{5} q^{2}(1-p)(1-q)\right\}$ \\
\hline ? 00 & 1 & $\frac{1}{5} p^{2}(1-q)^{2}$ \\
\hline ? ? $\bigcirc x$ & 1 & $\frac{1}{5} p q(1-p)(1-q)$ \\
\hline$? ? \times 0$ & 1 & $\frac{1}{5} p q(1-q)^{2}$ \\
\hline$? \times ? \bigcirc$ & $\frac{1}{2}$ & $2\left\{\frac{1}{5} p q(1-p)(1-q)+\frac{1}{5} p q(1-q)^{2}\right\}$ \\
\hline$? \times \times ?$ & $\frac{1}{2}$ & $3\left\{\frac{2}{5} q^{2}(1-p)(1-q)\right\}$ \\
\hline ? ? $\bigcirc$ ? & $\frac{1}{2}$ & $\frac{2}{5} p(1-p)(1-q)^{2}$ \\
\hline ? ? $\times \times$ & $\frac{1}{2}$ & $\frac{1}{5} q^{2}(1-p)^{2}+\frac{1}{5} q^{2}(1-p)(1-q)$ \\
\hline ??? & $\frac{1}{2}$ & $\frac{1}{5} p(1-p)(1-q)^{2}+\frac{1}{5} p(1-q)^{3}$ \\
\hline$? ? \times ?$ & $\frac{1}{3}$ & $3\left\{\frac{1}{5} q(1-p)^{2}(1-q)+\frac{2}{5} q(1-p)(1-q)^{2}\right\}$ \\
\hline ? ? ? $\times$ & $\frac{1}{3}$ & $\frac{2}{5} q(1-p)^{2}(1-q)+\frac{1}{5} q(1-p)(1-q)^{2}$ \\
\hline ?? ? ? & $\frac{1}{5}$ & $\frac{3}{5}(1-p)^{2}(1-q)^{2}+\frac{2}{5}(1-p)(1-q)^{3}$ \\
\hline \multicolumn{2}{|c|}{ 計 } & 1 \\
\hline
\end{tabular}


表 5. 二項モデルとターミナル・モデルによる正答率分布と平均正答率(単一式)

\begin{tabular}{c|c|c|ccccc}
\hline \multirow{2}{*}{ 事象 } & \multirow{2}{*}{ 正答率 } & \multirow{2}{*}{ 二項モデル } & \multicolumn{5}{|c}{ ターミナル・モデル } \\
\cline { 4 - 7 } & & & 1 肢 & 2 肢 & 3 肢 & 4 肢 & 5 肢 \\
\hline$E_{1}$ & 1 & 0.531 & 0.100 & 0.200 & 0.300 & 0.412 & 0.531 \\
\hline$E_{2}$ & $\frac{1}{2}$ & 0.125 & 0.000 & 0.000 & 0.050 & 0.100 & 0.125 \\
\hline$E_{3}$ & $\frac{1}{3}$ & 0.188 & 0.000 & 0.150 & 0.225 & 0.225 & 0.188 \\
\hline$E_{4}$ & $\frac{1}{4}$ & 0.125 & 0.400 & 0.400 & 0.300 & 0.200 & 0.125 \\
\hline$E_{5}$ & $\frac{1}{5}$ & 0.031 & 0.500 & 0.250 & 0.125 & 0.063 & 0.031 \\
\hline \multicolumn{2}{r}{ 平均正答率 } & 0.094 & 0.300 & 0.400 & 0.500 & 0.600 & 0.694 \\
\hline
\end{tabular}

$p=q=0.5$ の場合

表 6 . 二項モデルとターミナル・モデルによる正答率分布と平均正答率 (2 連式)

\begin{tabular}{c|c|c|ccccc}
\hline \multirow{2}{*}{ 事 象 } & \multirow{2}{*}{ 正答率 } & \multirow{2}{*}{ 二項モデル } & \multicolumn{5}{|c}{ ターミナル・モデル } \\
\cline { 4 - 7 } & & & 1 肢 & 2 肢 & 3 肢 & 4 肢 & 5 肢 \\
\hline$E_{1}$ & 1 & 0.563 & 0.000 & 0.150 & 0.350 & 0.488 & 0.563 \\
\hline$E_{2}$ & $\frac{1}{2}$ & 0.312 & 0.200 & 0.300 & 0.300 & 0.300 & 0.312 \\
\hline$E_{3}$ & $\frac{1}{3}$ & 0.094 & 0.300 & 0.300 & 0.225 & 0.150 & 0.094 \\
\hline$E_{4}$ & $\frac{1}{4}$ & 0.000 & 0.000 & 0.000 & 0.000 & 0.000 & 0.000 \\
\hline$E_{5}$ & $\frac{1}{5}$ & 0.031 & 0.500 & 0.250 & 0.125 & 0.062 & 0.031 \\
\hline \multicolumn{2}{r|}{ 平均正答率 } & 0.781 & 0.400 & 0.450 & 0.600 & 0.700 & 0.781 \\
\hline
\end{tabular}

連式よりも難かしいと結論づけるのは早計であろう。 $p=q=0.5$ の場合の平均正答率の大小比較のみによっ て，出題形式による難易度を論ずることは適切でない と思われる。選択肢の質的な難易性やそれらの配列が 難易度の重要な要因になると思われるが，選択肢の理 解できる確率と選択肢の配列に限定して，単一式の平 均正答率と二連式のそれを比較するにしても，各選択 肢を理解できる確率が等しくないときには，二連式の 平均正答率が単一式より小さくなる場合が生ずる。た と学ば二連式での○群, ×群の境界周辺にむずかしい 選択肢すなわち $p, q$ の值が小さい選択肢を配置する
等の工夫をすれば，二連式の平均正答率を単一式より 小さくすることもできるであろう。

また正答肢はすべて同じ確率 $p$, 不正肢はすべて同 じ確率 $q$ で理解できる場合でも式 (5.6)，(5.7) を満足 する $p, q$ の組(たと学ば $p=0.8, q=0.2$ ) に対して, 2 項モデルでは二連式の平均正答率 (0.844) は単一式の それ（0.850）より小さくなる.

5）ターミナル・モデルの二連式では区後の選択肢 のとりだし方として隣接方式を採用したが，囚後には 隣接方式の注かに1つとびに選択肢を選ぶ方式や，隣 接方式と1つとびの方式との混合方式などが考光ら 
れこれらの方式についても隣接方式と同様にして知 識の状態の生起確率を算出することができる.

6）選択肢の理解については，受験者は正答肢を正 答か不明，不正肢を誤りか不明かのいずれかしか理解 できないと考党たが，実際にはこのような慎重な判断 をせず誤判断すなわち正答肢を誤り，不正肢を正答と みなすことにもとづいて，解答コードを決定する。こ の誤判断による得点の増減 (Horst, 1966) をも考慮し た得点分布について，今後の課題として研究を行ない たい。

またここでは不十分な知識の状態を，5個の選択肢 のうち何個の選択肢を正, 不正, 不明のどんな組合せ で知っているかといら形で構成したが, 実際には何個 の選択肢の知識が欠落しているかといらよりは，1つ
の選択肢の判断そのものにあいぬいさがあること，す なわち選択肢を正答, 愦りと峻別できないことに起因 している場合が多いこのような不完全な知識の状態 については別の角度からの研究が必要であろう。

\section{参 考 文 献}

Chernoff, H. (1962): The scoring of multiple choice questionnaires. Ann. Math. Stat., 33, 375-393.

Horst, P. (1966): Psychological measurement and prediction, Wadsworth, 214-215.

池田 央 (1973)：テスト II，255-259, 東京大学出版 会, 東京.

印東太郎, 小野 茂, 池田 央 (1977): 心理測定·学 習理論 (テスト・スコアの理論) 56-68, 森北出版, 東京.

- 1982 年 4 月受付, 1982 年 9 月再受付一 